\title{
NEVER-AGING STORIES: AGE, MASCULINITY AND THE WESTERN MYTH IN SYDNEY POLLACK'S THE ELECTRIC HORSEMAN
}

\author{
EVA PELAYO SAÑUDO \\ Universidad de Cantabria \\ eva.pelayo@unican.es
}

Received 26 April 2020

Accepted 7 July 2020

KEYWORDS: aging, masculinity, western, cowboy, horses

PALABRAS CLAVE: envejecer, masculinidad, western, cowboy, caballos

\begin{abstract}
According to Gabriela Spector-Mersel there are no cultural models for old men, in comparison to the easily available scripts in early and middle adulthood. As such, this is a considerably unsettling phase of negotiation for men as they need to (re)define their identity and their sense of masculinity particularly when aging. The masculinity embodied by the cowboy prototype certainly fits this model that sees masculinities as a "temporal script" (67). In the classic 1979 movie The Electric Horseman, directed by Sydney Pollack, the factor of age runs as a subtext that not only informs masculine identity but also takes on a broader significance to express an important cultural transformation. Instead of simply focusing on the effects of the passing of time for an individual man, the film explores the changes in US society through one of its most celebrated cultural icons, the cowboy. To analyze Sonny Steele's distinctiveness within hegemonic ageless narratives in The Electric Horseman, this article will set him alongside two archetypal figures of the genre of the western: the cowboy and the horse, which serves as a key vehicle of the character's own exalted masculinity. This critical approach shows how the prevailing model of youthful or ageless masculinity in cowboy stories can thus be challenged.
\end{abstract}

RESUMEN: Según Gabriela Spector-Mersel, no existen modelos culturales para los hombres en la etapa de la vejez, en comparación con las representaciones ampliamente disponibles en la juventud o en la edad adulta. Por ello, se trata de una dificil fase de negociación para los hombres que necesitan (re)definir su identidad y su sentido 
de la masculinidad al envejecer. La masculinidad encarnada por el prototipo del vaquero se ajusta especialmente a este modelo que considera las masculinidades sujetas a un "guión temporal" (67). En la clásica película The Electric Horseman, dirigida por Sydney Pollack en 1979, el factor edad funciona como un subtexto que no solo informa la identidad masculina sino que también expresa una transformación cultural más amplia. En lugar de centrarse simplemente en los efectos del paso del tiempo para un hombre individual, la película explora los cambios en la sociedad estadounidense a través de uno de sus iconos más reconocidos, el vaquero. Para analizar el carácter distintivo de Sonny Steele dentro de las narrativas hegemónicas sobre la edad en The Electric Horseman, el artículo lo examina a través de dos figuras arquetípicas del género western: el vaquero y el caballo, el cual sirve fundamentalmente como mecanismo de expresión de la masculinidad del personaje. Esta aproximación crítica muestra la posibilidad de cuestionar el modelo predominante de esa masculinidad anclada en una juventud eterna en las historias de vaqueros.

\section{NEVER-AGING STORIES IN POPULAR CULTURE}

While gender studies normally incorporate the analysis of men and women across the differentiating categories of class, race and sexuality, the intersection between age and masculinity remains largely untheorized: "most studies focus on just one or two parts of the intersecting axes, such as masculinities and class or masculinities and sexualities. These ageless endeavors maintain a pluralistic ignorance of 20 percent or more of the population of men in most Global North countries" (Thompson, Men, Masculinities, and Aging 4). As a result, age studies constitute a growing field trying to address some of these theoretical gaps, "the absence of a life span time perspective in masculinity scholarship and thus men's studies emphasis on never-aging masculinities" (5). According to Gabriela Spector-Mersel there are no cultural models for old men, in comparison to the easily available scripts in early and middle adulthood. In fact, the representation of old men is often "ungendered" (67). As such, this is a considerably unsettling phase of negotiation for men as they need to (re)define their identity and their sense of masculinity particularly when aging. Sally Chivers is also of the opinion that our culture clings to an idea of masculinity that is ageless. In The Silvering Screen: Old Age and Disability in Cinema, she mentions how many male actors, unlike the female counterparts, 
Never-Aging Stories: Age, Masculinity and the Western Myth in Sydney Pollack's The Electric Horseman

continue to play the same kind of roles they were given in their youth. In addition, she argues that as age becomes a potential menace to one man's virility, a large effort is made to compensate for this vulnerability. Film portrayals then tend to expose traditional markers of masculinity that are exaggerated such as dominance over women or minorities. In other words, to avoid these gender anxieties, a perceived sense of a fading masculinity eventually turns into an increased virility, into an attempt to reaffirm power and control, sometimes "at the expense of others" (101).

The masculinity embodied by the cowboy prototype certainly fits this model that sees masculinities as a "temporal script" inasmuch as age is a crucial factor that affects the subjectivity and identity of both women and men (Spector-Mersel 67). This is explored through the textual and visual revision of a particularly suitable classic example that has not been considered from this perspective. In the 1979 movie The Electric Horseman, directed by Sydney Pollack, the protagonist's mature age is never explicitly alluded in the film as a reason for the hero's demise. Audiences are not explained what caused Sonny's downfall from his glorious past to his present meaningless life. Yet I argue that the factor of age runs as a subtext that not only informs masculine identity but also takes on a broader significance to express an important cultural transformation. Instead of simply focusing on the effects of the passing of time for an individual man, the film explores the changes in US society through one of its most celebrated cultural icons, the cowboy.

Mei-Chen Lin and Paul Haridakis have questioned the "problematic presentations" of the aging hero in media genres, including the western, and how they reflect stereotypes about the aged. For example,

At times, age itself is not a strength, but an infirmity that he must overcome to accomplish something heroic. The aging hero succeeds in spite of his age, not because of it [...] sometimes, the hero dies sacrificing himself to save others-suggesting that it is okay for him, or maybe expected of him, to make this sacrifice, because he is old. He has lived his life, and the lives of those he saves are of greater value for the future. Although the sacrifice is often voluntary-as the hero's last chance to be visible in a heroic fashion-old age, once again, is marginalized. (26) 
At the same time, there is a "long-established connection between the West and the youth trope" (Rio 152). Indeed, this is part of larger cultural prescriptions that have created an overpowering model presuming the equation between youth and masculinity. As Edward Thompson notes,

To all intents and purposes, growing older seems to be outside conceptualizations of masculinity. In most discourses one can be masculine and one can be old, but not both. [...] Normative masculinity became and remains embodied by middle-age and younger men, both in the mass culture and in men's studies. ("Guest Editorial" 1)

By contrast, the film analyzed deconstructs the association of masculinity to a temporal script of youth by inscribing successful aging through the main character, as it will be shown. To analyze Sonny Steele's distinctiveness within hegemonic ageless narratives in The Electric Horseman, this article will set him alongside two archetypal figures of the genre of the western: the cowboy and the horse. The cowboy is not only the epitome of mainstream masculinity but also, and relatedly, of a protagonist who never seems to age: "Traditionally, the cowboy hero (exemplified by the Lone Ranger) has been portrayed as an ageless guarantor of unchanging truth and justice. ... Aging successfully (or, for the fantastical Lone Ranger, not aging at all) remains tied to the performance of youthful masculinity scripts" (Saxton and Cole 99). Cowboys, as much as they are admired by audiences worldwide, are a complicated vehicle of identification by offering a very limited representation of masculine identity. This prevailing model of youthful masculinity in cowboy stories can thus be challenged by using Spector-Mersel's theoretical alternative in that "failing to take into account old age, these are essentially incomplete scripts" (67).

In The Electric Horseman film, Sonny (Robert Redford) is presented as a famous rodeo rider who is at the very end of his career since he goes from being hailed in the newspapers' headlines "five-times all-around world champion Cowboy" to being simply described as a "cereal cowboy." He now works for the entertainment industry and for the multinational corporate Ampco by promoting its breakfast cereal, Ranch Breakfast. He appears in TV and all kind of parades wearing a cowboy costume with flashing lights and riding a horse that is also decorated, just as the protagonist, the actor 
Never-Aging Stories: Age, Masculinity and the Western Myth in Sydney Pollack's The Electric Horseman

playing the Lone Ranger in several films, Clayton Moore, also dressed up in commercials and parades for many years after the show. When Moore became "too old" for the audiences to notice the difference from the ageless hero he used to star, he was legally constrained to halt such public appearances. Apparently, the 65-year-old Moore represented a menace to the creator of the TV show, who was planning the release of a film version (Saxton and Cole 103-4). This comparison shows the extent to which the image of success for the cowboy is so clearly associated to a younger hero, bearing a resemblance to the film's protagonist.

All in all, The Electric Horseman effectively addresses the ageless script of the archetypal hero in the western and opens up a space for a model of late-life masculinity. In turn, the horse plays an important role in the film thematically and in terms of its imagery and underlying message. The stallion Rising Star not only serves to retake this essential companion in the genre, but also stands as a useful counterpoint for outlining the protagonist's transition from an ageless to the aging cowboy. The character's development and his coming to terms with himself are traced as Sonny rescues a thoroughbred horse from exploitation in the media industry and releases him into freedom.

\section{ON THE TRAIL TO FREEDOM: NATURE (HORSE) / MODERNIZATION (CONSUMERISM)}

While The Electric Horseman has been classified as a comedy, it is a happy-ending tragedy about the passing of an era, of a cultural icon and of ageless masculinity. It is a meditation on both individual and national identity as it juxtaposes the fading world of rodeo culture and cowboy popularity, and the incipient consumer and corporate culture: "The movie takes place in the West, where the new image-based culture, epitomized by Las Vegas, coexists with an older economy of ranches and towns that still maintains some sense of connection to the still older economy of the Old West" (Sanes n.p.). Considering the plot as well as the date of release, the film can be contextualized within a new age of production in the 1960s that revolved around "the end of the west(ern)" (Baker 134). This is a final chance or performance for many of the classical directors or actors in westerns. As Brian Baker claims in "Old Age Westerns," included in this category are "Sam Peckinpah's Ride the High Country (1962), for which Randolph Scott temporarily came out of retirement; Don 
Siegel's The Shootist (1976), John Wayne's last film; and Unforgiven (1992), so far Clint Eastwood's last Western" (133). Baker continues that another defining feature is the "self-conscious exploitation of the West as a myth" (134; emphasis in original), which is a pattern particularly noticeable in The Electric Horseman. In all these films,

the West is transformed into a spectacle, into a commodity that allows the surviving heroes of the past to turn a few dimes and cling on. The West is exploited by the remaining 'frontiersmen' because they have no other choice: [...] the world of the frontier has been replaced by the world of economics. (133)

As it is disclosed later, Sonny fits the common portrayal of how the central characters (or "superannuated heroes" in Baker's words) in these westerns are somehow an anachronism and the sense that they have "outlived their time" (134). Although many of the so-called revisionist westerns after the 1960s are associated with the demythification of the values and modes of representation in previous films (Hoffman 1997), The Electric Horseman is classified within a context of "re-mythification:" "un western ecológico de Sydney Pollack situado temporalmente en la época de su realización, el personaje de Robert Redford escapa a la banalización de la nueva América erigiéndose en el último baluarte del antiguo Oeste" (González 102). Even if the actual setting of the Old West is perhaps changed beyond recognition and its disappearing economy is pushed away, the film ratifies a revival of the western as an artistic genre not only by endorsing the main character's point of view but also by replaying its main conventions such as through the opposition nature/modernization, which are respectively represented by the horse and consumer culture.

As the media and Ampco corporation in the film economically exploit both Sonny and a \$12-million thoroughbred horse (Rising Star) the underlaying message is that abandoning civilization and embracing nature is, as in traditional westerns, the main raison-deêtre for the protagonist. Like the typical hero in the western, Sonny struggles to escape the evils of a modernized world which is represented by the greed of the media and the new economic system. The Electric Horseman characteristically depicts this mythical quest for freedom, on top of a horse as well as thanks to him. The horse not only embodies nature but is the very double of the protagonist 
Never-Aging Stories: Age, Masculinity and the Western Myth in Sydney Pollack's The Electric Horseman

and serves to explicitly discuss unresolved issues of masculinity and age.

The Electric Horseman tells the tale of a lost life and the mourning for it after middle-age, signaling a new turning point in which the hero tries to purse his own path of development. Opening scenes combine newspaper cuts showing Sonny's past achievements and adverts about his current job as a TV star for the selling of cereal. At first, it appears he has actually gained more visibility or continues to being celebrated: "His image is on billboards and lifesize cutouts, like the Marlboro Man; he is promoted as a living symbol of the Wild West to sell Rach Breakfast to the children of America" (Leonelli 56). Yet it soon becomes clear Sonny does not fit in that world. He appears drunk and disillusioned before the audiences. At one time, he even falls off the horse, just after a closeup to his foot trying to reach the stirrups has also made evident that he does need help to even get on it. Moreover, when in company of friends, Sonny openly disapproves of the modern and luxurious lifestyle in which somehow unexpectedly they are: "we're living like a bunch of barons" (Pollack 8:39-8:40) In fact, he often references back to his former life as a rodeo champion and later acknowledges when confronting the Ampco managers that he was "pretty good at it" (22:02-22:04) which functions as a contrast to his current feelings of failure and lack of a purpose.

Thus, Sonny resembles other protagonists of the "Old Age Westerns" who are depicted as "relics of a bygone, heroic time" (Baker 134). More importantly, the factor of aging is particularly considered as a recurring pattern of exclusion: "These men have 'outlived their time,' adrift in a modernity in which their skills and attributes have no utility or value [...] In some ways, this superannuation is a response to the ageing stars of the Western itself" (145). According to Lin and Haridakis, "the aging hero caught between two worlds" is a typical setting, intended to show the moral choices to the changes in society, as is also the case in The Electric Horseman:

the plot involves an older America giving way to a more modern one. The qualities of the past with which the aging hero is comfortable are either presented as something that has to be discarded, or as qualities so important that they should be adopted and incorporated in a newer modern America, and the aging hero serving as the bridge. (23) 
Upon discovering that a thoroughbred horse is also abused in the media studios and deciding to release it, Sonny finally finds the external motif he wants to drive himself to freedom. By stealing Rising Star from the company, Sonny initiates an escape from Vegas into the desert trying to reach the Rym Rock Canyon in Utah, which parallels his own quest for (a lost) identity. He thus becomes a cowboy turned runaway as he is labelled a horse thief, the one to be chased with charges of kidnapping the horse: "Having invented Steele as an idealized hero, [Ampco] will now reinvent him as a villain" (Sanes n.p.). The company goes to great lengths to arrest him on the grounds that the horse is in great danger. When becoming concerned that they may lose the signature of an important commercial agreement because of the loss of the horse, the magnates even resort to publicly airing Sonny's private life and destroying his reputation. They magnify the story that his alcohol addiction, as well as his potential aggressivity, represent a real threat for the horse's wellbeing: "We could make sure that if he speaks to anyone, he won't be believed. Can you get to the media by the 11 o'clock news?" (Pollack 46:30-46:37). Not only the lack of scruples of corporations is exposed but the manipulative power of the media is also demonized and, in fact, apart from the police, Sonny escapes from the press.

Reporter Hallie Martin (Jane Fonda), who works for New York TV, is desperate to get the news about the story of the theft and is intent on finding Sonny. After discovering Sonny but having a strong dispute and failing her objectives, she first appears reporting about the stealing of the "greatest money winner in the history of American racing and presently corporate symbol for one of the world's largest conglomerates" (44: 07'-44:13). Hallie actually shares the same views as to the economic value of the horse, which can be again exploited by turning its celebrated release into pure marketing: "when Steele gets there, he's gonna turn Rising Star loose. What? $\$ 12$ million worth of thoroughbred racehorse loose in horse heaven. Think you got a story? Stick with the lunatic, Hallie. Tape everything. This is gold" (59:11-59:26).

Coming from the 'civilized' East, Hallie is a further representative of the modern threat of consumerist power that the cowboy hero successfully manages to defy. Hallie's essential role in the film follows the "The Cowboy and the Lady" formula as it resembles other famous filmic couples in the western (the likes of Gary Cooper and Merle Oberon or John Wayne and Jean Arthur) 
Never-Aging Stories: Age, Masculinity and the Western Myth in Sydney Pollack's The Electric Horseman

where the women are also instructed in the wild (Canby n.p.). Hallie's urban ways (represented by her fancy shoes) are often mocked and clearly contrasted with the hero's more authentic pursuit, which is thus typically diminished by the company of women. Sonny initially rejects her and complains that "I've got nothin' but miles of open country to cross. Now I'm carryin' a crazy woman around, wearing shoes from Bloomingbergs" (Pollack 1:14:11-1:14:14). According to Laura Mulvey's analysis of westerns, one of the primary roles of women therein is that of signifying the hero's "marriageability" as a proper "narrative closure" (33). Yet the opposite function is equally satisfactory and recurrent: "in the Western it [marriage] can be accepted [...] or not. A hero can gain in stature by refusing the princess and remaining alone" (33). This other role allows the hero to retain "a nostalgic celebration of phallic, narcissistic omnipotence" (33). This explains Sonny's growing fondness for Hallie but eventual rejection of a relationship. Fitting a typical representation, he is certainly vacillating "between two points of attraction, the symbolic (social integration and marriage) and nostalgic narcissism, [which] generates a common splitting of the Western hero into two" (34). As we shall see later, The Electric Horseman deflects a romantic attachment in that it compromises the hero's solitude and search for freedom, which are particularly central elements of the western.

Before falling in love with her, Hallie also becomes a suitable companion in his quest through the desert and an ally to (re)claim his identity by amending the media distortions and allowing him to tell the audiences his own story. Sonny decides to fight back and have his say into what Ken Sanes rightfully identifies as a "a war of demonizing and idealizing images," given that Hallie "conveys a real but over-heroized image of his good self and good intentions that will undo the misleading image created by Ampco" (n.p.). In fact, although Hallie voices the quintessential journalists' uncompromised search for truth, she early takes sides and equally buys into the traditional version of the myth of the West:

I'm just trying to earn an honest buck, tell an honest tale. I don't want to make up a story about you. What have you got to lose? What's the big secret? Everybody wants to know. They're wondering where you're going, why you did it. You know, the truth about the great American cowboy and the world champion horse [...] riding together into the sunset. (Pollack 42:57-43:11) 
The myth of the West and its legendary cowboy on horseback is thus endorsed by mainly resorting to a classical depiction of iconic representations together with binary oppositions which contribute to shape opinion into a well-defined message. By doing this, the cowboy is exalted as its image becomes relived into a modern version within a shifting world. Not by chance a horse becomes Sonny's closest companion, clinging to a basic convention of the western genre, as well as restating notions of masculinity that the association with that animal allows. For this reason, it is worth exploring the representation of the specific relationship between man and horse in thefilm.

\section{BECOMING CENTAUR: "IF I COULD DRIVE SLEEPIN' THE WAY YOU SLEEP STANDIN"”}

Scholarly interest in horses has examined their historical and artistic relevance as allegories or symbols as well as signifiers of very specific cultural and political contexts. From a gender perspective, horses are variously thought to convey crucial information about men's and women's roles in addition to sexuality. For example, in "Romancing the Horse: Adventure and Femininity in Juvenile Equine Fiction for Girls," Ellen Singleton examines a wellknown genre (pony or horse series) which functions as a key instrument of female educational and sexual development. Using varying patriarchal conventions through time, this apparently appealing genre equally "downplayed female adventure and controlled constructions of femininity as caring, maternal, heterosexual and dependent on masculine leadership and strength" (92). Other analyses of women's relationships to horses have also concentrated on the pedagogical and gendered nature of such encounters (as well as prevailing class relations and race issues). In this special bond for a free-spirited protagonist, the animal partner is usually conceived as an erotic male substitute and the girl's obsession is admitted as a temporary stage before developing more acceptable relations through heterosexual love or marriage (Halley, 2019; McHugh, 2011). Regarding men, in Becoming Centaur: Eighteenth-Century Masculinity and English Horsemanship, Monica Mattfeld focuses on the classic practice of English Horsemanship informing ideas of masculinity in addition to class and national identity. Although her analysis is mostly circumscribed during a 
Never-Aging Stories: Age, Masculinity and the Western Myth in Sydney Pollack's The Electric Horseman

particular time period, the metaphor of the man-centaur is apt to explore the way in which representations of horses are commonly blended with gender assumptions, particularly with ideals of masculinity. In this case, the thoroughbred in The Electric Horseman functions as an updated version of the cowboy's most fundamental companion as well as a key vehicle of the character's own exalted masculinity. Drawing on Stella Hockenhull,

Whether it is a contemporary or traditional example from the Western, the horse operates as a significant element in the genre. It functions as a vehicle to enable mobility; it symbolizes freedom through its links with the wilderness and nature, and it advances the notion of masculinity in that it aids its rider in success. (175)

This interpretation can be further traced by examining the horsehuman relationship which is mostly based on several identifications. As Sonny, Rising Star is a former champion at the races but is now drugged so that he stays calm and looks better when recording in the studios. This triggers an immediate reaction and sympathy on the part of the main character that makes also explicit for the audience the identification of man and horse. In fact, the love for the horse reconnects the alienated Sonny to his former self, reflected in the moving speech about the horse's misuse which symbolizes the need to shed off the fake identity adopted in contemporary life and go back to one's true nature:

I'm gonna get him back to where he was, what he was. It's in his blood. He knows what to do, he's just half forgot is all. But he's a thoroughbred race horse. He's delicate. Maybe it isn't gonna work. Maybe it won't work. Maybe he ain't gonna make it. Where you gonna do this? But at least he's gonna try, have his own shot at it. (Pollack 55:55-56:10)

As doubts about the possibility of success emerge, what counts most is individual freedom and the right to pursue the quest for one's identity. The value of individualism at the expense of failure and in the face of any obstacle is thus endorsed. At this point, when Sonny is asked if they are lost, he is surprised about the question, "Lost? No" (1:23:23-1:23:28), and he appears to have actually found where he belongs. 
In fact, the quest for the horse's freedom can be read as the narrative device that allows the protagonist to initiate his own quest to regain a lost identity. Director Pollack "wanted to make a fairy-tale Western with an optimistic ending, where the disillusioned cowboy, through the love for his horse, rediscovers his true self in the simplicity of nature" (Leonelli 55). As Leo Pando also notes in "Golden Stallion, Silver Screen," "While [The] Electric horseman may be seen as a diatribe against unbridled corporate power and an attempt to make people aware of big business injustices and animal rights, it's fundamentally about self-redemption" (171). When Sonny passionately defends Rising Star, the scripted words reflect a doubleintended discourse that could apply to his own miserable situation: "he's one of the best. He's one of the greatest animals in the ... in the history of ... animals. Maybe they bought him. Maybe they own him. But there are some rights you can't buy, even from an animal" (Pollack 54:07'-54:46). The fact that Sonny is referred to as the Ampco Cowboy in the media reflects that he himself is also supposed to belong to the company. Furthermore, the great qualities of the thoroughbred stallion are continuously emphasized and finally reveal the primary cause of its breed. Rising Star is a 'true' or natural champion which, similarly to Sonny, is destroyed by greedy commercial interest. There is also the concern that the effect of such abuse on the horse can make it impossible to further "breed him," which can betray Sonny's anxieties about his own masculinity:

Have you ever seen this horse race? Have you ever seen him? I've seen him run. I saw him stumble, fall back and lose his stride, and pick himself up. I saw him stretch himself out when he had nothin' left to give, but he found it ... somewhere. And he won. Lady, that horse is a champion, and he's got a heart the size of a locomotive. He's got more heart and more drive, and more... soul than most people you'll ever know. And they're hangin' lights all over him. They're trottin' him around on stages with dancin' girls. Ta-ta-da-data-ta! They'd have him wearin' short. They'd have him wearin' short pants and smokin' a cigar ... if they thought it'd sell their damn junk! Look it.! They got him all tanked up on tranquilizers and Bute. They're stickin' him full of needles! Look at this tendon! It's all filled up. He's shot all full of steroids. And it's just for looks. Makes the horse sterile. (Pollack 52:18-53:07)

More specifically, The Electric Horseman provides an unusual narrative of cowboys as aging men, showing that "masculinity 
Never-Aging Stories: Age, Masculinity and the Western Myth in Sydney Pollack's The Electric Horseman

remain[s] important for the identity construction of these older men who, rather than becoming un-gendered in their old age [...] still str[i]ve to achieve masculine ideals" (Foweraker and Cutcher 469). It thus can be related to more recent cultural products that "question the widely held assumption that aging is a lesser concern for men, or that men and women's aging experiences may be simply defined as opposed" (Armengol 1). The emasculating effects pervading the imagination of men are associated to varying reasons ranging from aging, the fear of 'castration' posed by women, to economic deprivation that threatens the cultural mandate of male financial success (6). The Electric Horseman particularly addresses the factor of youth and the distance from femininity as traditional symbols of masculinity. That masculinity remains important for Sonny's identity is proved by the association of the horse's fine qualities to his breed and fertility, as well as by the possibility of adulterating his 'purity' through the lights put on him and being reduced to appear in a show of dancing girls. It is perhaps no coincidence that Sonny meditates about such masculine ideals of strength, courage and endurance that are projected over the horse or that he worries about a feminizing contamination. At one point, Sonny also muses about the possibility of acquiring some of the horse's natural abilities so that he is more powerful in beating his enemies: "If I could drive sleepin' the way you sleep standin,' we'd have this thing licked" (Pollack 36:05-36:10). Rising Star proves invaluable to help in Sonny's desire for greater speed and existential freedom altogether. The horse puts all his prowess when they both star the five-minutes epic chase from the police (1:03:30-1:08:05) and eventually conducts Sonny to the longed greener spaces, just as in the classic western reunion of man and nature:

Just as Jack and his horse Whisky in Lonely Are the Brave confront modernity and progress, desiring a return to a simpler existence, so Sonny and Rising Star confront mechanization in a contemporary world. Cornered by police motorbikes, and encountering farm machinery, they achieve an escape through terrain impassable to human-made vehicles. The animal's prowess and the rider's guile assure their escape and, from an overhead shot, man and horse are seen galloping along a promontory toward a sunlit river. (Hockenhull 174) 
In this case, Sonny mounts easily and quickly on the horse and shows excellent horsemanship skills: he crosses rivers, jumps over fences and effectuates difficult turns and halts. After he manages this escape from several police cars and motorbikes ("at least a dozen cops," Hallie says in worry-Pollack 1:03:06-1:03:08), the magnates' alarm increases and all institutional power is called into action with desperate agitation

How did he get away? On a horse. On a horse. Find him. Bring them back here. Use the F.B.I. Use the state police. Use helicopters. Put out a reward, a large one. Get the Boy Scouts. Get the Marines. Where is he? Utah? Get the Mormon Tabernacle Choir. Have them sing him in, but get him! (1:08:06-1:08:23)

Not only this heroic reputation is achieved thanks to the horse, but the most fundamental relationship of mutual trust between man and horse is also established, which signals Sonny's significant transformation through regained independence and self-confidence. When Hallie cautions that "You can't make it out there!" with so many policemen, Sonny caresses the horse and replies "It's gonna be up to him. Okay now, Junkie, no excuses. Tendon's goin' down, you ain't wheezin' anymore. And goddamn, I've seen you run. Let's go" (1:03:08-1:03:15). Sonny alludes to the horse's physical wellbeing, which during the journey he has himself closely supervised as each night Sonny nurses him; he "tends to the animal's wounds and obtains herbs to steam the drugs out of his system, talking to him throughout and referring to him in familiar terms as 'son" (Hockenhull 173). In turn, as the horse's performance proves to be in full force once again, Sonny's (self-)esteem is restored.

Furthermore, his masculinity is exalted, "challenging the conventional equation of men's aging processes with (sexual) decline" (Armengol 1). While tending to him, Sonny again addresses Rising Star and declares that he is indebted to him (Pollack 1:09:061:09:07). Hallie confirms the main character's significant transformation by admiring Sonny's success: "You should've seen yourself. You were great. You were" (1:09:16-1:09:19). It is at this point that the image of the hero begins to resurface, given that his escape or supposed theft is presented on the grounds of his sound principles about the horse's well-being. The TV broadcasts his reproving discourse about the horse's exploitation (1:10:00-1:10:37). This means that the entire diatribe about the horse's exploits and 
Never-Aging Stories: Age, Masculinity and the Western Myth in Sydney Pollack's The Electric Horseman

menaced fertility is again repeated and stylistically amplified as it is visually rendered through different TV screens, thus making sure that this particular message gets to every home in the country.

After that, the hero's quest resumes. His relation to Hallie also changes and becomes more intimate. Her own opinions about Sonny as a transformed hero finally translate into a romantic attachment, which is enhanced through the dim light and the tune of a harmonica playing after they have dinner in a caravan. As Sonny goes to sleep saying that "It's gonna be a long way, lady. A long way" $(1: 12: 26-1: 12: 28)$, she is left looking closely at this typical representation of the cowboy lying with his hat on his eyes $11: 12: 34-$ $1: 12: 42$ ). Before the romance is more definitely established at the end of the film though, Sonny is still concerned about the burden of femininity to his quest, thus foregrounding his masculinity, which is once more narrated through his relationship to the horse. For example, Sonny refuses to help Hallie carrying her work's equipment as they need to travel light and he then starts being disdainful again about the inconvenience of her expensive boots. He totally becomes mad at the possibility that Hallie takes her equipment on Rising Star, affirming twice: “it ain't goin' on my horse" (1:14:21-1:14:23). This claim of ownership goes no unnoticed to Hallie, who answers back: "Your horse!" (1:14:25-1:14:26). As it turns out, Sonny will reclaim exclusive bonding. When Hallei asks about the final destination of their quest and she for once compares herself to the horse Rising Star, she is rebuked and denied such an identification:

[Hallei:] Isn't there some closer place where you guys ... take horses to let 'em go? I just usually use the one, myself. It's so pretty here. If I were Rising Star, I'd love... [Sonny:] We'll, you're not. C'mon. Do me a favor, will you? Don't go tryin' to think like a horse. I'll worry about him. (1:20:24-1:20:34)

Finally, since ageing and masculinity norms are deeply entangled, age runs as an understated explanation too of the character's concern. Both Sonny and the horse were once champions. The fact that thoroughbreds' racing career, because of the intense physical demands, is limited to their younger years can make us infer that Sonny's career as a cowboy is also temporal. In this case, as it is explored below, he rather faces the demands of "a social clock" (Spector-Mersel 70) whereby mainstream scripts of masculinity are associated to a certain age. 


\section{4. "MAMAS, DON'T LET YOUR BABIES GROW UP TO BE COWBOYS:" YOUTH FANTASY AND THE COWBOY HERO}

The Electric Horseman opens with a horse running unbridled accompanied by the lyrics that make allusion to the past, in particular to the memories of growing up with the dream of becoming one of the most sung heroes, the cowboy. The song "My Heroes Have Always been the Cowboys" thus anticipates the main theme of a passing age through the remembrance of a feverish dream that is now long gone. The song is a clear voiceover for the protagonist Sonny, who is no longer young nor a 'real' cowboy. The lyrics tell us "I let the words of my youth fade away/Old worn-out saddles, and old worn-out memories," and the images confirm this lament about a more glorious past; we see billboards with his name and shows where Sonny is defined as what he has become, the Ranch Breakfast Cowboy or simply the Ampco Cowboy.

As also conveyed by the soundtrack "Mamas, don't let your babies grow up to be cowboys," youth fantasy plays a fundamental role in upholding an idealized version of a hero which is particularly enshrined in US culture. Thus, the film expresses that one of the most obvious "social clocks" (Spector-Mersel 70) that a to-be cowboy must consider is the need to confront the romance of the myth. By perfectly tracing the transcendence of certain vital moments (work, marriage, death) and ultimately revealing Sonny's character, this song also functions as an adequate voiceover for his disappointments in later life. According to this song, there is something wrong with children choosing to "pick guitars and drive old trucks" rather than being "doctors and lawyers," which is resonant with the professional trajectory of Sonny. His ability to secure a livelihood is severely compromised when, after being a successful rodeo rider, he is left with the prospect of becoming a TV star. He is shown to feel greatly alienated as he is led into pretending to be a very particular version of whom he thought he was; as Sonny plays the commercial story of the cowboy, he becomes a shadow who doubtfully resembles his former self.

In addition, the character's identity is most obviously split. This is clearly expressed in the early scene where he appears disillusioned in a lift and is reflected in the mirror, which foregrounds his feeling entrapped and divided. Moreover, the alienated self is also explicitly alluded to in the trope of fakeness 
Never-Aging Stories: Age, Masculinity and the Western Myth in Sydney Pollack's The Electric Horseman

pervading references to the new entertainment industry. This discourse allows us to identify a fundamental cultural critique about how the image of the cowboy has been massively appropriated and distorted. Sanes explains the initial scene when Sonny appears drunk at a show:

a double is put in his place, riding around with electric lights-a fake impersonating a fake. 'That's not me' he says in disbelief, as he watches his double do his act. 'They don't know the difference,' one of the producers of the show sardonically tells him, making clear that the movie is pointing a finger of blame at the public for allowing itself to be manipulated by this culture of image. (n.p.)

In other words, the media in the film is the evident foil which is demonized as an artificial mechanism to uphold false depictions, while ignoring that the representation of the 'real' cowboy relies on a similar construction that privileges certain cultural narratives. As discussed earlier, when it is Sonny who gets to tell his own story or what Hallie terms "the truth," the result is an equally interested or mediated version, precisely the opposite "over-heroized image" (n.p.).

The soundtrack song later traces a cowboy's living, particularly during his adult life, in solitude, which is one of the most charismatic descriptions associated to the prototype. Whereas the cowboy's solitude has been generally seen as a positive signifier of freedom and independent masculinity when in youth, the song seems to imply that this is not necessarily a virtue when in old age. Children are also discouraged from being cowboys as "They'll never stay home and they're always alone/Even with someone they love," which is also the case of the protagonist given that he is abandoned by his wife precisely because he was never home. Furthermore, as the sung hero is mostly miscomprehended, if lucky to reach an old age he is doomed to be abandoned: "if you don't understand him and he don't die young/You'll probably just ride away."

Finally, the song that closes the film ("Hands on the Wheel") emphasizes the hero's solitude as we see Sonny hitchhiking just after he has released Rising Star and said goodbye to Hallie, who is offered a temporary job position in Paris. In his last conversation with her, Sonny insists on the need for privacy and begs her not to reveal the whereabouts of Rising Star. Accordingly, his own destiny is a mystery. The camera slowly zooms out to the road and the openness 
of the landscape, which are to be understood as Sonny's true home, as the lyrics express:

At a time when the world seems to be spinnin'. Hopelessly out of control. There's deceivers and believers. And old in-betweeners. That seemed had no place to go. But it's the same ol' song. It's right and it's wrong. And livin' is just somethin' that I do. And with no place to hide. I looked in your eyes. And I found myself in you. I looked to the stars. Tried all of the bars. And I'd nearly gone up in smoke. Now my hand's on the wheel. Of somethin' that's real. And I feel like I'm goin' home. And I feel like I'm goin' home. (1:53:43-1:55:18)

Accompanied by the harmonica, the song thus retakes the typical motifs of the male quest in the western, the classic story of an outsider who is bound to wander alone. As Jeffrey Wallmann has noted, the roaming motif has traditionally prevailed over any other depiction of everyday activities: "the wanderlust freedom associated with cowboy life [...] has seemed enviably romantic" (86). The references to "old in-betweeners" and "ol'song" certainly allude to the archetypical or common features of such a story. However, it can also be read as a veiled indication of the character's old age in that just as the world changes, so he is. In this sense, the film effectively addresses the prevailing model of ageless masculinity in cowboy stories. In this case, Sonny has also ultimately become a legend, which is ageless. As Hallie reports by the end of the film, "So ends the bizarre saga of horse racing's most honored stallion... and the man who set him free" (Pollack 1:53:25-1:53:30). Although Hallie personally thanks Mr. Steele for having helped to bring the story to public attention, what remains in the end is the story itself. Sonny has no place in it as an individual; it is the story of an unnamed as well as ageless man and his horse.

That the film concludes with this message reinforces the need to further reinvent conventional scripts that assume that a man's life necessarily finishes after he has completed his greatest exploits when in youth. The film itself is a testimony that the formation of the self and, particularly, the performance of masculinity, continues to be played in later life as Sonny has certainly succeeded in pursuing freedom and becoming a hero by liberating another being from abuse. To sum up, after the different explorations of masculinity and allusions to aging, this happy ending inscribes new discursive configurations in the structure of the 
Never-Aging Stories: Age, Masculinity and the Western Myth in Sydney Pollack's The Electric Horseman

western, fundamentally the ongoing need to deal with one's identity, no matter the age.

\section{WORKS CITED}

ARMENGOL, Josep. "Aging as Emasculation? Rethinking Aging Masculinities in Contemporary US Fiction." Critique: Studies in Contemporary Fiction, vol. 59, no.3, 2018, pp. 1-13.

BAKER, Brian. "Old Age Westerns." Masculinity in Fiction and Film: Representing Men in Popular Genres, 1945-2000, Continuum, 2006, pp. $124-143$

CANBY, Vincent. "Screen: Redford-Jane Fonda Comedy: Cowboy and the Lady." The New York Times, 1979.

CHIVERS, Sally. "Yes, We Still Can: Paul Newman, Clint Eastwood, Aging Masculinity, and the American Dream." The Silvering Screen: Old Age and Disability in Cinema, University of Toronto Press, 2011, p. 99120.

FOWERAKER, Barbara, and Leanne Cutcher. "Work, Age and Other Drugs: Exploring the Intersection of Age and Masculinity in a Pharmaceutical Organization." Gender, Work \& Organization, vol. 22, no. 5, 2015, pp. 459-473.

GONZÁLEZ, José Félix. "El atardecer del Oeste y su presente histórico." El héroe del western crepuscular: dinosaurios de Sam Peckinpah, Fundamentos, 2007, pp. 100-108.

HALLEY, Jean. "Dreaming of Horses: The Pony Book Genre and Other Horse Stories in the Mid-Twentieth Century." Horse Crazy: Girls and the Lives of Horses, University of Georgia Press, 2019, pp. 74-103.

HOCKENHULL, Stella. "Horse Power: Equine Alliances in the Western." Love in Western Film and Television Lonely Hearts and Happy Trails, edited by Sue Matheson, Palgrave, 2013, pp. 161-179.

HOFFMAN, Donald. "Whose Home on the Range? Finding Room for Native Americans, African Americans, and Latino Americans in the Revisionist Western." Melus, vol. 22, no. 2, 1997, pp. 45-59.

LEONELLi, Elisa. Robert Redford and the American West. Xlibris Corporation, 2007. 
LIN, Mei-Chen and PAUL Haridakis. "Golden Agers, Recluses, and John Wayne: Aging Stereotypes and Aging Heroes in Movie Westerns." Aging Heroes Growing Old in Popular Culture, edited by Norma Jones and Bob Batchelor, Rowman \& Littlefield, 2015, pp. 15-31.

MATTFELD, Monica. Becoming Centaur: Eighteenth-Century Masculinity and English Horsemanship. The Pennsylvania State University Press, 2017.

MCHUGH, Susan. "Velvet Revolutions: Girl-Horse Stories." Animal Stories: Narrating Across Species Lines, University of Minnesota Press, 2011, pp. 65-115.

MULVEY, Laura. "Afterthoughts on 'Visual Pleasure and Narrative Cinema' Inspired by King Vidor's Duel in the Sun (1946)." Visual and other Pleasures, Palgrave, 1989, pp. 29-38.

PANDO, L. Trigger: The Lives and Legend of Roy Rogers' Palomino. North Carolina: Mcfarland and Company, 2019.

POLLACK, Sydney, director. The Electric Horseman. 1979. Performance by Robert Redford and Jane Fonda. DVD Columbia Pictures and Universal Pictures, 2004.

RÍO, David. "Facing Old Age and Searching for Regeneration in a Dying American West: Gregory Martin's Mountain City." Atlantis, vol. 38, no.1, 2016, pp. 149-164.

SAXTON, Benjamin, and Thomas Cole. "No Country for Old Men: A Search for Masculinity in Later life." International Journal of Ageing and Later Life, vol. 7, no. 2, 2012, pp. 97- 116.

SPECTOR-MERSEL, Gabriela. "Never-Aging Stories: Western Hegemonic Masculinity Scripts." Journal of Gender Studies, vol. 15, no.1, 2006, pp. 67-82.

SANES, Ken. "The Electric Horseman: Escape from the Desert of Images."Transparency,2000.

https://transparencynow.com/horseman.htm

SINGLETON, E. "Romancing the Horse: Adventure and Femininity in Juvenile Equine Fiction for Girls." Gender and Equestrian Sport: Riding Around the World, edited by Miriam Adelman and Jorge Knijnik, Springer, Dordrecht, 2013, pp. 91-110. 
Never-Aging Stories: Age, Masculinity and the Western Myth

in Sydney Pollack's The Electric Horseman

THOMPSON, Edward. Men, Masculinities, and Aging: The Gendered Lives of Older Men. Rowman \& Littlefield, 2019.

THOMPSON, Edward. "Guest Editorial." The Journal of Men's Studies, vol.13, no. 1, 2004, pp. 1-4.

WALLMANN, Jeffrey. The Western: Parables of the American Dream. Texas Tech UP, 1999. 